\title{
The Westminster Confession in the Church of Scotland today
}

\author{
Introduction
}

David Fergusson

Produced in 1646 by the Westminster Assembly in London, the Westminster Confession of Faith (WCF) was adopted the following year by the General Assembly of the Church of Scotland as its principal subordinate standard. It replaced the Scots Confession of 1560. A consensus statement of Reformed orthodoxy framed by the doctrine of election and the covenant scheme, the WCF provides a clear and measured account of Christian doctrine. Its practical concerns are evident in chapters devoted to the Christian life and to subjects such as church discipline, marriage and divorce, the civil magistrate, and the taking of oaths.

Within the Scottish Presbyterian churches, ministers and elders are required to subscribe to the WCF on the occasion of their ordination. Although the formula of subscription has changed and Declaratory Acts have introduced various qualifications concerning its interpretation, the WCF has remained the subordinate standard of the Church of Scotland since 1647. This status was retained at the time of church union in 1929 and expressly confirmed in the second Declaratory Article of the Church of Scotland which describes the WCF as 'containing the sum and substance of the Faith of the Reformed Church'. This expression was evidently a compromise between those who were anxious about rigid adherence to a set of doctrinal standards and those who wished the Church of Scotland explicitly to uphold the catholic faith. At any rate, nobody sought to specify the substance of the faith that was 'contained' in the WCF. ${ }^{1}$

Since the 1970s, several attempts have been made to revise the church's confessional position. These have been animated mostly by a concern that the WCF is no longer studied or respected. The theological position of the church has de facto moved some way from the expression of Reformed orthodoxy in the midseventeenth century. A confessional position that acknowledges this shift has thus been urged. Since the last attempt at confessional reform in 1984, the issue has remained in the background awaiting further resolution. To this end, the Presbytery of Melrose and Peebles brought an overture to the 2018 General

${ }^{1}$ For discussion of the drafting process see Douglas M. Murray, Freedom to Reform: The 'Articles Declaratory' of the Church of Scotland 1921 (Edinburgh: T\&T Clark, 1993), 21-42. 
Assembly instructing the Theological Forum to revisit the issues with particular reference to the role of a subordinate standard, the formula of subscription and the potential value of a book of confessions.

With this in view, the Theological Forum held a conference at New College on 8 May 2019. Papers were presented by Paul Nimmo, Stafford Carson, Amy Plantinga Pauw, and David Fergusson. These have now been reproduced for publication. Our hope is that they will contribute to further constructive discussion in the church as it addresses the questions surrounding its principal subordinate standard.

David Fergusson

New College

1 August 2019 